\title{
Women Entrepreneurs and The usage of social Media for Business Sustainability In the time of Covid-19
}

Ninik Sri Rahayu ( $\nabla$ ninik.srirahayu@uii.ac.id)

Islamic University of Indonesia: Universitas Islam Indonesia https://orcid.org/0000-0001-6784-4556

Masduki Masduki

Islamic University of Indonesia: Universitas Islam Indonesia

Nur Ellyanawati Esti Rahayu

Islamic University of Indonesia: Universitas Islam Indonesia

\section{Research}

Keywords: Women entrepreneurs, social media, sustainability, COVID-19

Posted Date: September 17th, 2021

DOI: https://doi.org/10.21203/rs.3.rs-907854/v1

License: (c) (i) This work is licensed under a Creative Commons Attribution 4.0 International License.

Read Full License 


\title{
WOMEN ENTREPRENEURS AND THE USAGE OF SOCIAL MEDIA FOR BUSINESS SUSTAINABILITY IN THE TIME OF COVID-19
}

\author{
Ninik Sri Rahayu* \\ Department of Banking and Finance, Islamic University Indonesia \\ Masduki \\ Department of Communication, Islamic University Indonesia \\ Nur Ellyanawati ER, \\ Department of Banking and Finance, Islamic University Indonesia
}

\begin{abstract}
This study explores the efforts of Indonesian women entrepreneurs to sustain their businesses during the COVID-19 crisis of 2020-2021. Focusing on female-owned businesses in Yogyakarta, this research places particular emphasis on how social media contributes to their survival. Using a quantitative approach to analyze data collected from 130 respondents, the researchers found that the pandemic has severely affected women entrepreneurs - especially those operating SMEs. Most significantly, women have experienced reduced income due to decreased sales, disrupted supply chains, and difficulty paying credit instalments. Although women entrepreneurs are particularly vulnerable to economic shocks, most lack access to assistance from government and private programmes. This study also sheds light on social media's Important role in saving women's businesses. Facebook, WhatsApp, and Instagram have become the main instruments through which women market their businesses and reach new audiences. Aggressive promotions, accompanied by attractive offers such as discounts and additional services, have helped women entrepreneurs reduce their losses. Overall, we conclude that women entrepreneurs found innovative ways to survive their businesses during a time of crisis.
\end{abstract}

Keywords: Women entrepreneurs; social media; sustainability; COVID-19

\section{Introduction}

The COVID-19 pandemic has significantly disrupted all areas of the economy (Fendel, et al., 2020). Particularly affected by the pandemic, however, have been micro and small enterprises (MSEs) (Kaur \& Kaur, 2020; Shafi et al., 2020). In this arena, female entrepreneurs face more difficult challenges than their male peers, as they must overcome obstacles such as limited access to financial resources, lack of networks/mentors, and gender biases (Halabisky, 2017; Villaseca et al., 2020). Womenowned businesses also face problems such as balancing work and family, finding and keeping qualified employees, and adapting to technological and marketplace changes (Mandishaya et al., 2015). In the developing world, women entrepreneurs must also deal with cultural and traditional mores that provide less support, emphasise motherhood, position women as subordinate to men (particularly their husbands), and limit their mobility. More so than their male counterparts, women entrepreneurs' family ties impede the growth, sustainability, and performance of their businesses (Etim, 2020; Naidu, 2010). Women entrepreneurs are left 'triple blind', facing problems with financial capital, human capital, and social capital (Danish \& Smith, 2012). 
The COVID-19 crisis has been particularly detrimental for women entrepreneurs. Unlike earlier economic recessions, which primarily affected the businesses operated by men, the pandemic has left women more vulnerable (Alon et al., 2020). Dependence on informal financing and limited assets have proven significant challenges. Women tend to be concentrated in the industries most affected by the pandemic, have relatively small financial buffers, and lack access to different financial sources. On average, their businesses are smaller and younger than male-owned businesses. They are more likely to be self-funded or funded by friends and family (OECD, 2021). Other studies have confirmed that COVID-19 has disproportionately affected women entrepreneurs. Kritikos et al. (2020), for instance, reported that female self-employed were $35 \%$ more likely to experience revenue loss than men, and that women-owned businesses laid off a disproportionally higher share of their workers.

Women entrepreneurs' struggles during the pandemic have been compounded by the network limitations that prevent them from accessing mentoring and crisis management services (Henry, 2020). Furthermore, their access to government relief programmes is often hampered by eligibility issues; assistance programs generally prioritise MSEs that have developed a relationship with commercial lenders, while women entrepreneurs rely more on informal financing (Orser, 2020). Women entrepreneurs have thus turned to the digital economy to expand their customer base and the scope of their business. A recent survey in Indonesia indicated that women-owned businesses are more likely to use the internet to sell products. It is estimated that 54 per cent of women-owned microbusinesses now use the Internet to sell products (UN Women, 2020). To cope with these difficulties, women have adopted a range of cash management, flexibility, cooperation, and digital marketing strategies (Sultan \& Sultan, 2020). As such, social media has emerged as a saviour for many businesses, as entrepreneurs both big and small have used it to reach their customers and provide them with the required products and services (Kaur \& Kaur, 2020).

Studies on the effectiveness of social media in the development of SMEs have been conducted in many countries (Aloulou, 2019; Bernhard \& Grundén, 2016; Fleet, 2012; Jones et al., 2015). Previous studies have also examined the relationship between social media and women entrepreneurs (Cesaroni et al., 2017; Etim, 2020; Genç \& Öksüz, 2015; Mukolwe \& Korir, 2016; Olsson \& Bernhard, 2020; Ukpere et al., 2014). Studies by Kaur and Kumar (2020); Kaur and Kaur (2020); and UN Women (2020) have demonstrated that tapping into online markets has become a critical coping strategy for business owners during the COVID-19 pandemic. However, there is still limited empirical evidence on social media and women's entrepreneurship during the pandemic. As such, this research aims to explore Indonesian women entrepreneurs' usage of social media for business sustainability during the pandemic. This study contributes to the literature by exploring women-owned MSEs and their social media usage during the COVID-19 pandemic.

This paper is organised as follows: Section 1 discusses the background of the research. This is followed by a review of the relevant literature in Section 2. Section 3 discusses the research design, data collection, and analysis methods. In Section 4, the findings of this study are discussed. Finally, in Section 5, the conclusions, managerial implications, and limitations of this study are discussed.

\section{Literature Review \\ Women and Entrepreneurship}


Entrepreneurship refers to the business activities undertaken by persons with initiative, innovation, and decision-making skills, as well as specific capital and responsibility (Cadar \& Badulescu, 2015). Entrepreneurs, thus, are those who create their own business, i.e., persons who organise, operate, and assume the risks of business ventures (Garg \& Eisenhardt, 2017). Hence, women entrepreneurs are simply women who participate in entrepreneurial activities and take risks by combining resources in a unique way, thereby enabling them to take advantage of opportunities in their immediate environment by producing goods and services (Mordi et al., 2010).

However, entrepreneurship has long been synonymous with men. The construction of entrepreneurship as a masculine phenomenon has deep historical roots, which are supported by cultural and economic processes and embedded in social and cultural attitudes and norms (Hamilton, 2013). Gender biases in entrepreneurship are associated with the fact that entrepreneurship has traditionally been understood as a male gender role (Gogar, 2019). As a consequence, women entrepreneurs appear invisible; they do not seem to fit the stereotypes, even though they play an essential role in developing the economy and creating jobs (Javadian \& Singh, 2012; Sharma, 2018). Zeb and Ihsan (2020) emphasised that economic development is impossible without involving women. In other words, women's involvement is foundational for economic growth, and entrepreneurship is the most likely option for them (Ismail et al., 2016).

Enterprises where more than 51 per cent of capital originate from women and 51 per cent of employable positions are allocated to women can be characterised as femaleowned (Vijayakumar \& Jayachitra, 2013). Female-owned businesses are generally small enterprises that engage in the trade and service sector (Sandri \& Hardilawati, 2019). In Indonesia, nearly 40 per cent of all MSEs are women-owned (UN Women, 2020). Although women contribute substantially to the country's economic growth, many (if not most) women business owners opt to remain small and informal. According to Wei (2018), women-owned MSEs in Indonesia face several push and pull factors when deciding whether to remain small or expand their businesses. The demands of household domestic duties, as well as other time constraints, are major reasons for their decision to remain small and informal. Women's access to capital is also constrained; even when loan products are available, they do not necessarily fit their needs.

\section{Social Media and Small Business}

The use of social media is growing amongst contemporary businesses because it provides a relatively affordable, pervasive, user-friendly, and accessible platform that individuals can use in their private lives (Högberg, 2018; Högberg \& Olsson, 2019; Kaur $\&$ Kumar, 2020). Social media is very beneficial for small businesses, which often have limited resources to market their products (Barnes et al., 2012). Among the various social media platforms, Facebook and Instagram are preferred by small entrepreneurs, as they are simpler and require less technical knowledge than Blog, Google+, or LinkedIn (Genç \& Öksüz, 2015). These platforms are designed in such a way that users can share personal data and interact online (Zuboff, 2015).

Social media is not merely an instrument for disseminating information. It also offers friendship-based business tools that enable businesses to communicate, listen to, and learn from customers in ways they have never done before (Jones et al., 2015). For women entrepreneurs, social media offers business opportunities and provides means to change the discourses and expectations about women entrepreneurs (Cesaroni et al., 2017). While the world of entrepreneurship is frequently described as a masculine area 
(Gogar, 2019), social media can present successful women entrepreneurs as role models. In line with that, Markowska et al. (2018) stated the importance of forefronting innovative women entrepreneurs as influencers on social media. This idea is in line with the concept of digital entrepreneurship, where entrepreneurs can find new ways of doing business based on digital technology, such as by transforming offline businesses into online ones (Kraus et al., 2018).

\section{Research Methodology}

The research questions of this study are two-fold. First, to what extent has the COVID-19 pandemic impacted women entrepreneurs? Second, how have women employed social media to cope with the pandemic? To answer these questions, this work employs a quantitative approach to describe women entrepreneurs and their usage of social media during the COVID-19 outbreak. The research population is female entrepreneurs who actively use social media platforms such as WhatsApp, Facebook and Instagram in managing their businesses. The respondents are founders and business owners who have been in business for at least two years. Initial data for this study was obtained from the "Warung Rakyat", a website developed by the COVID-19 task force at the Islamic University of Indonesia to promote MSE products in Yogyakarta during the pandemic. Women entrepreneurs listed on the website were then selected purposively based on their specific subsector (i.e. food, beauty, fashion, and crafts). Subsequent data collection used the snowball technique, wherein respondents identified other potential respondents.

Due to the unknown population of women entrepreneurs in Yogyakarta using social media, the sample size was determined following the formula developed by Lemeshow et al. (1997), as follow:

Where:

$$
n=\frac{Z^{2} \cdot 1-\propto / 2 \cdot P(1-P)}{d^{2}}
$$

$\mathrm{n}$ : sample size; Z: standard normal variate corresponding to the level of significance $(95 \%)=1.96$; : expected prevalence $=0.5$; d: absolute error or precision.

Based on this formula, the minimum sample size was calculated as below:

$$
\begin{gathered}
n=\frac{1,96^{2} \cdot 0.5(1-0.5)}{0,1^{2}} \\
n=96.4=100
\end{gathered}
$$

The researchers collected data from 130 respondents, and thus met the minimum sampling requirement. Questionnaires were distributed to respondents via WhatsApp. Each questionnaire had two sections; the first collected demographic information on the respondents, while the second gathered information about women entrepreneurs, their businesses, their operations, and their use of social media to ensure business sustainability during the COVID-19 pandemic.

\section{Results and Discussion}

Demographic characteristics of the respondents 
To understand the connection between women entrepreneurs and social media in the context of the COVID-19 pandemic, it is necessary to first explore their demographic characteristics. Table 1 summarises the information on all 130 respondents, with a particular focus on five indicators: age, education level, business sector, source of initial capital, and number of employees.

Table 1Demographic characteristics of respondents

\begin{tabular}{|c|c|c|c|c|}
\hline \multicolumn{5}{|c|}{ Age } \\
\hline$<25$ & $25-34$ & $35-44$ & $45-54$ & $>55$ \\
\hline $4.61 \%$ & $28.5 \%$ & $33.1 \%$ & $29.2 \%$ & $4.61 \%$ \\
\hline \multicolumn{5}{|c|}{ Education level } \\
\hline \multicolumn{2}{|c|}{ Secondary High School } & Diploma & Bachelor & $\begin{array}{c}\text { Post- } \\
\text { Graduate }\end{array}$ \\
\hline \multicolumn{2}{|c|}{$33.8 \%$} & $16.2 \%$ & $48.5 \%$ & $1.5 \%$ \\
\hline \multicolumn{5}{|c|}{ Business sector } \\
\hline Food & Beauty & Fashion & Craft & Other \\
\hline $40.15 \%$ & $3.03 \%$ & $18.94 \%$ & $4.55 \%$ & $5.30 \%$ \\
\hline \multicolumn{5}{|c|}{ Source of initial capital } \\
\hline $\begin{array}{l}\text { Personal } \\
\text { savings }\end{array}$ & $\begin{array}{l}\text { Spouse and } \\
\text { family }\end{array}$ & $\begin{array}{l}\text { Financial } \\
\text { institution }\end{array}$ & \multicolumn{2}{|c|}{ Others } \\
\hline $70.7 \%$ & $17.7 \%$ & $8.5 \%$ & \multicolumn{2}{|c|}{$3.1 \%$} \\
\hline \multicolumn{5}{|c|}{ Number of employees } \\
\hline 0 & \multirow{2}{*}{\multicolumn{2}{|c|}{$\begin{array}{c}1-3 \\
27.27 \% \\
\end{array}$}} & \multirow{2}{*}{\multicolumn{2}{|c|}{$\begin{array}{c}>3 \\
17.43 \% \\
\end{array}$}} \\
\hline $55.3 \%$ & & & & \\
\hline
\end{tabular}

The majority of respondents $(66 \%)$ were female entrepreneurs under the age of 45 (Table 1). This may have influenced their adoption of new business strategies using the internet, mobile applications, and other information and communication technologies that are more familiar to younger users (Kozubíková et al., 2016). Moreover, the higher prevalence of entrepreneurial activity among women between the ages of 25 and 44 could be attributed to the fact that these individuals have had the time and education to develop their skills and knowledge, as well as the experience necessary to develop confidence in their own abilities (Zali et al., 2018).

Table 1 also shows that education levels were relatively high among respondents. Approximately $66 \%$ received some form of tertiary education, and the remaining $33 \%$ had some secondary education. Education plays an essential role in entrepreneurship, as it provides women with the skills necessary to identify opportunities, establish a business, and make decisions effectively. All of these are crucial aspects of entrepreneurship, as they have a direct impact on profitability, growth rates, job formation, and value creation (Ahmadov et al., 2021). Entrepreneurs with higher levels of education are significantly more likely to innovate than entrepreneurs with little to no education. Higher education seems to be one of the factors determining the success of businesses (Hunady et al., 2018). Hence, the high level of formal education among respondents indicates that these women entrepreneurs had sufficient knowledge to successfully run their businesses.

As also seen in Table 1, 40\% of respondents were involved in the culinary sector. This figure seems to be in line with national data, which indicate that most Indonesian MSEs operate in the culinary sector. The Ministry of Finance has deemed this 
sector to be the most significant contributor to the nation's economic growth. The remainder of the female entrepreneurs were engaged in other business sectors. Of these, most were active in the fashion (28\%) and retail (17\%) sectors; fewer were involved in the craft $(5 \%)$ and beauty $(3 \%)$ sectors.

Most respondents $(70 \%)$ indicated that the initial capital for their businesses came from their personal savings. This result supports the findings of previous studies, which have found that women mostly start businesses with internal capital sourced from personal savings (Bennett \& Dann, 2000; Orser et al., 2006). Only 3\% of respondents received their seed capital from formal financial institutions such as banks or microfinance. According to Chowdhury et al. (2018), women entrepreneurs face greater obstacles in accessing such institutions due to their lack of information, collateral, guarantor, and experience, as well as discriminatory laws.

Approximately $40 \%$ of respondents indicated that they carried out all business activities without any employees; of the remainder, some $27 \%$ employed one to three persons and $17 \%$ had more than three employees. These findings are in line with those of Powers and Magnoni (2013), who note that women-owned MSEs tend to have fewer employees than male-owned MSEs and are more likely to use temporary labour. Furthermore, this figure suggests that women are more likely to operate microenterprises, i.e. the smallest companies.

\section{The Impact of COVID-19 on Women-owned business}

Table 2 The Impact of Covid-19 on Women-owned Businesses

\begin{tabular}{ll}
\hline Criteria & Percentage \\
\hline Decline in sales & $87 \%$ \\
- Yes & $13 \%$ \\
- No & $35 \%$ \\
\hline Supply chains & $32 \%$ \\
\hline Raw material and production & $23 \%$ \\
Delivery and distribution & $9 \%$ \\
Communications with the customers and suppliers & \\
Other (employees unable to work due to the lockdown, & \\
tested positive for COVID-19) & $42 \%$ \\
\hline Loans from financial institutions & $58 \%$ \\
Yes & $47 \%$ \\
- No & $29 \%$ \\
\hline Strategy for repaying loans & $24 \%$ \\
l. Rescheduling & \\
1.Selling assets & \\
2. Other (reducing working hours for employees, & \\
borrowing money from family) & $81.5 \%$ \\
\hline Assistance related to the pandemic & \\
Yes & \\
No &
\end{tabular}


With the sharp downturn in economic activity, women who operate MSEs have been particularly vulnerable to losing their livelihoods. In line with global trends, almost $87 \%$ of women surveyed confirmed that their sales had decreased since the beginning of the COVID-19 pandemic. Large-scale social restrictions (PSBB) led to a drastic decline in economic activity, as people were less likely to spend in these uncertain conditions, and this is suspected to have caused a decline in demand for MSE products (UNDP \& LPEM UI, 2021). However, approximately $13 \%$ of women micro-entrepreneurs indicated that the pandemic did not affect their MSEs.

The pandemic also severely disrupted the supply chains used by entrepreneurs. The 130 women entrepreneurs surveyed experienced problems with raw material and production $(35 \%)$, delivery and distribution (32\%), and communication with customers and suppliers (23\%). Another 9\% indicated that they had faced other problems, such as employees being unable to work due to lockdown policies or testing positive for COVID19. Women-owned MSEs were particularly vulnerable to these issues, as they typically have weaker supply chains, smaller inventories, and limited supplier networks, making them more vulnerable to supply chain disruptions (WTO, 2020). Together, these problems reduced the sales and profits of women-owned MSEs.

One of the main challenges faced by women entrepreneurs was their limited access to formal financial institutions. In many cases, women entrepreneurs are not considered bankable as they are unable to meet the criteria for receiving loans from formal financial institutions. Most operate in sectors with lower capital intensity and on a smaller scale, and this further exacerbates their difficulty seeking external funding (World Bank Group, 2016). Table 2 shows that only $42 \%$ of the women entrepreneurs surveyed received loans from formal financial institutions. To overcome their drastically reduced revenue, most women MSE owners sought to reschedule their loans (47\%). Other strategies included selling assets, borrowing money from family and friends, and reducing the working hours of their staff.

Without access to financial coping strategies, women also had difficulty accessing government support and stimulus programmes. Since the onset of the pandemic, the Government of Indonesia has implemented several stimulus packages to benefit both businesses and individuals, including social assistance programmes, direct cash transfers, working capital loans, and credit guarantees (UN Women, 2020). However, almost 81\% of women micro-entrepreneurs surveyed did not benefit from any of these programmes (Table 2). Government relief programmes have not specifically targeted women-owned MSEs, which has in practice prevented women from benefitting from them.

\section{Women entrepreneurs and social media usage}

Table 3 Women entrepreneurs and social media usage

\begin{tabular}{cccc}
\hline \multicolumn{4}{c}{ Reason for using social media for business } \\
\hline $\begin{array}{c}\text { User friendly } \\
70 \%\end{array}$ & Affordable & \multicolumn{3}{c}{ Trend \& market demand } \\
$23.8 \%$ & $6.2 \%$ & \\
\hline \multicolumn{4}{c}{ Experience using social media } \\
\hline $1-2$ years & $3-4$ years & $>4$ years \\
$45.4 \%$ & $30 \%$ & $24.6 \%$ \\
\hline Intensity using social media during the pandemic \\
\hline 1 hour & $1-5$ hours & $6-10$ hours & $>10$ hours \\
$10.7 \%$ & $60 \%$ & $26.2 \%$ & $3.1 \%$ \\
\hline
\end{tabular}




\begin{tabular}{|c|c|c|c|c|}
\hline \multicolumn{5}{|c|}{ Main means of accessing social media } \\
\hline $\begin{array}{c}\text { Cellular } \\
\text { phone } \\
69.8 \%\end{array}$ & $\begin{array}{c}\text { Cellular phone } \\
\text { \& tablet } \\
5.4 \%\end{array}$ & $\begin{array}{c}\text { Cellular phone } \\
\text { \& Laptop } \\
23.8 \%\end{array}$ & $\begin{array}{r}\text { Cellular pho } \\
\text { Lap } \\
1\end{array}$ & $\begin{array}{l}\text { e, Tablet, \& } \\
\text { op } \\
\text { to }\end{array}$ \\
\hline \multicolumn{5}{|c|}{ Social media platforms used } \\
\hline WhatsApp & $\begin{array}{l}\text { WhatsApp \& } \\
\text { Facebook }\end{array}$ & $\begin{array}{l}\text { WhatsApp \& } \\
\text { Instagram }\end{array}$ & $\begin{array}{l}\text { WhatsApp, } \\
\text { Facebook, \& } \\
\text { Instagram }\end{array}$ & $\begin{array}{c}\text { Other } \\
\text { combination }\end{array}$ \\
\hline $26.9 \%$ & $7.7 \%$ & $13.1 \%$ & $45.55 \%$ & $6.9 \%$ \\
\hline
\end{tabular}

Because of its affordability, which enables women entrepreneurs to overcome their limited financial resources, social media plays a vital role in the development of women-owned MSEs (Jones et al., 2015). Likewise, social media provides an easy, userfriendly, and very economical platform for rapidly disseminating information to diverse markets; as such, it has paved the way for the growth of women entrepreneurs (Duggal \& Gupta, 2020). Supporting previous findings, most of the respondents in this study $(70 \%)$ used social media for their MSEs because of its user-friendliness; another $23.8 \%$ of respondents chose social media due to its affordability. A smaller percentage of respondents $(6.2 \%)$ chose social media to follow market demands and trends.

According to Melissa et al. (2013), Indonesian women have increasingly used social media for their businesses because this digital platform is very easy to operate. Through social media, users can tag pictures and provide product information to potential customers with a single click (Melissa et al., 2015). In Indonesia, of the 549,740 users registered on Facebook as the owners of small and medium enterprises, 176,300 are women (Melissa et al., 2013). Women use social media platforms such as Facebook as a strategy to increase sales and communicate with customers (Ukpere et al., 2014).

In this survey, $45 \%$ of respondents had used social media for their business for 12 years. This indicates that the majority of respondents were relatively new social media users who likely began using the platform when the COVID-19 crisis began affecting their business. In other words, the pandemic likely encouraged women to seek alternative strategies, selling their products online when offline business activities were impossible. Rapidly embracing an online format enabled women to continue reaching customers during the lockdown, when face-to-face interactions were limited. At the same time, however, a relatively high percentage of women entrepreneurs had been using social media for 3-4 years (26\%) and more than four years (30\%). The majority of respondents $(60 \%)$ indicated that they spent $1-5$ hours using social media every day to run their business during the pandemic.

To access social media and conduct online business activities, respondents overwhelmingly $(69.8 \%)$ preferred using their cellular phones. Cellular phones are considered more practical and efficient, as they can be used for multiple purposes, and are thus preferred by entrepreneurs (Rahim et al., 2020). These digital devices have thus become pillars of socio-economic development, providing entrepreneurs with business opportunities and simplifying transactions (Melchioly \& Sæbø, 2010). This has changed the way entrepreneurs sell, purchase and interact with their suppliers and customers (Yahya \& Mutarubukwa, 2017).

To overcome the economic difficulties triggered by the pandemic, women entrepreneurs used a variety of digital platforms. Most $(45.55 \%)$ used WhatsApp in 
conjunction with Facebook and Instagram to expand their networks and make new connections with customers, suppliers, and peers. A smaller percentage combined WhatsApp with Instagram (31.1\%) or Facebook $(7.7 \%)$ or used another combination of platforms $(6.7 \%)$. At the same time, however, a significant number of women entrepreneurs (26.9\%) exclusively used WhatsApp to reach their customers. WhatsApp has long been the dominant app for daily personal communication in Indonesia. As such, it can easily be adapted for business use; entrepreneurs can tap into their existing networks and quickly start sharing photos and information about their business activities.

\section{Business sustainability and social media}

Table 3 Business sustainability and social media

\begin{tabular}{ll}
\hline \multicolumn{1}{c}{ Criteria } & Percentage \\
\hline Strategy to maintain business & \\
Promotion through social media (SM) & $27.6 \%$ \\
Offering discounts & $4.6 \%$ \\
Reducing employees & $0.8 \%$ \\
Product diversification & $2.3 \%$ \\
Additional services & $1.53 \%$ \\
Promotion through SM, offering discounts & $14.6 \%$ \\
Promotion through SM, reducing employees & $3.1 \%$ \\
Promotion through SM, product diversification & $1 \%$ \\
Promotion through SM, additional services & $6.2 \%$ \\
Promotion through SM, offering discounts, additional & $36.7 \%$ \\
services \& product diversification & $1.6 \%$ \\
Other combination & \\
\hline Marketing strategy through social media & $43.1 \%$ \\
Posting photos and videos related to the products & $54.6 \%$ \\
Posting photos and videos related to the products, \\
engaging in comments, \& develop friend networks \\
Other
\end{tabular}

To mitigate the deleterious effects of the COVID-19 pandemic and maintain their MSEs, women entrepreneurs have used various strategies. Some $36 \%$ of women combined four strategies - conducting promotions through social media, providing discounts, offering additional services, and diversifying their products - to save their businesses. Another $27.7 \%$ of respondents used a single strategy, focusing on increasing their social media presence by offering special promotions. Some women chose to combine two strategies, such as promoting products through social media and offering discounts $(14.6 \%)$. Of the strategies identified, laying off employees was the least commonly used $(0.8 \%)$.

As mobility was restricted by lockdown policies, people had more time to access social media. Female entrepreneurs thus exploited this opportunity to expand their reach. They saw increasing online sales through social media as a means of sustaining their businesses and mitigating losses. Social media offered them avenues to interact with consumers, even as social distancing policies prohibited physical contact. More than half of respondents (54\%) stated that posting photos and videos, engaging in comments, and 
building networks through social media were effective ways to market their products. Another $43.1 \%$ of women entrepreneurs expressed that posting photos and videos were the easiest way to promote their products.

\section{Conclusions}

This paper has investigated how women entrepreneurs have ensured the survival of their businesses during the COVID-19 pandemic by surveying 130 respondents in Yogyakarta, Indonesia. It has found that the COVID-19 crisis has profoundly impacted women-owned MSEs, resulting in reduced sales decline, supply chain disruption, and difficulty repaying loans from formal financial institutions. Although women entrepreneurs have been most vulnerable to this crisis, few have received assistance from government and non-government programmes. This research has also found that social media, especially WhatsApp, Instagram and Facebook, have emerged as significant tools for business promotion. It is predicted that the COVID-19 crisis will continue to push women entrepreneurs into the digital realm as they seek to reach a wider customer base. At the same time, they will continue providing discounts, offering additional services, and diversifying their products to cope with the COVID-19 pandemic.

Overall, this study explored the innovative ways that women have secured their businesses during a time of crisis. These findings are important, as they offer insight into how women entrepreneurs in a developing economy face the challenge of economic instability. The knowledge generated through this work may help reduce the unplanned losses that businesses face during times of crisis and help policymakers address the economic and social vulnerabilities of women entrepreneurs - especially when they are disproportionately affected, as in the current pandemic (Etim, 2020; Kaur \& Kaur, 2020; Villaseca et al., 2020). Future research must therefore consider how women deal with gender issues while managing their businesses. Expanding the research sample is also important to obtain a better understanding of the complex strategies through which women entrepreneurs in Indonesia deal with unexpected situations and crises.

\section{Abbreviations}

MSEs: Micro and Small Entreprises; COVID-19: Corona Virus Disease; OECD: Organization for Economic Co-operation and Development; UN: United Nations; UNDP: United Nations Development Program; LPEM UI: Lembaga Penyelidikan Ekonomi Masyarakat Universitas Indonesia; WTO: World Trade Organization.

Acknowledgments: The authors would like to thank all the participants in this study for their time and willingness to share their experiences and feelings.

Author Contributions: Conceptualization, N.S, and M; Methodology, N.S and M; software, N.E.; validation, N.S., and N.E; formal analysis, N.S and M.; investigation, N.S; M; N.E.; resources, N.E.; data curation, N.S and N.E; writing — original draft preparation, N.S.; writing - review and editing, M; visualization, M; supervision, M; project administration, N.E.; funding acquisition, N.S. and M. All authors have read and agreed to the published version of the manuscript.

Funding: This research was funded by Directorate of research and community service, Islamic University of Indonesia, grant number 006/Dir/DPPM/70. 
Availability of Data and Materials : All data generated or analysed during this study are included in this article. The raw data are available from the corresponding author upon reasonable request.

\section{Competing interests}

The authors declare that they have no competing interest.

\section{Reference}

Ahmadov, F., Zeynalova, U., Bayramova, U., \& Mammadov, I. (2021). Analysis of educational impact on women entrepreneurs in sustainable social business: the case of Azerbaijan. Turkish Journal of Computer and Mathematics Education (TURCOMAT), 12(6), 1847-1856.

Alon, T., Doepke, M., Olmstead-Rumsey, J., \& Tertilt, M. (2020). This time it's different: The role of women's employment in a pandemic recession. National Bureau of Economic Research.

Aloulou, W. (2019). Entrepreneurship and innovation in the digitalization era: Exploring uncharted territories. In Business Transformations in the Era of Digitalization (pp. 179-203). IGI Global.

Barnes, D., Clear, F., Dyerson, R., Harindranath, G., Harris, L., \& Rae, A. (2012). Web 2.0 and micro-businesses: An exploratory investigation. Journal of Small Business and Enterprise Development, 19(4), 687-711.

Bennett, R., \& Dann, S. (2000). The changing experience of Australian female entrepreneurs. Gender, Work \& Organization, 7(2), 75-83.

Bernhard, I., \& Grundén, K. (2016). Networking and e-government for local development-experiences gained by entrepreneurs in small enterprises in Sweden. International Journal of Entrepreneurship and Small Business, 29(2), 154-175.

Cadar, O., \& Badulescu, D. (2015). Entrepreneur, Entrepreneurship and Intrapreneurship: A literature review. Annals of Faculty of Economics, 2 (14), 658-664.

Cesaroni, F. M., Demartini, P., \& Paoloni, P. (2017). Women in business and social media: Implications for female entrepreneurship in emerging countries. African Journal of Business Management, 11(14), 316-326.

Chowdhury, T. Y., Yeasmin, A., \& Ahmed, Z. (2018). Perception of women entrepreneurs to accessing bank credit. Journal of Global Entrepreneurship Research, 8(1), 1-16.

Danish, A. Y., \& Smith, H. L. (2012). Female entrepreneurship in Saudi Arabia: Opportunities and challenges. International Journal of Gender and Entrepreneurship, 4(3), 216-235.

Duggal, R., \& Gupta, V. (2020). Impact of social media in the growth of business: A case study on women entrepreneurs. Benefits, 7(7), 3916-3921.

Etim, E. S. (2020). The utilization of social media platforms for viability of femaleowned small and medium-scale enterprises in South Eastern Nigeria. Acta Universitatis Danubius. Economica, 16(1), 96-111.

Fendel, R., Neugebauer, F., \& Zimmermann, L. (2020). Reactions of euro area government yields to Covid-19 related policy measure announcements by the 
European Commission and the European Central Bank. Finance Research Letters, Dec, 101917. https://doi.org/10.1016/j.frl.2020.101917

Fleet, G. J. (2012). Evidence for stalled ict adoption and the facilitator ecommerce adoption model in smes. International Journal of the Academic Business World, $6(2), 7-18$.

Garg, S., \& Eisenhardt, K. M. (2017). Unpacking the CEO-board relationship: How strategy making happens in entrepreneurial firms. Academy of Management Journal, 60(5), 1828-1858.

Genç, M., \& Öksüz, B. (2015). A fact or an illusion: Effective social media usage of female entrepreneurs. Procedia-Social and Behavioral Sciences, 195, 293-300.

Gogar, S. (2019). Women and business in the digital era: The impact of social media on the successes of female entrepreneurs in Trinidad and Tobago. Master thesis, Uthrecht University. Retrieved from file://Users/mac/Downloads/MSc\%20Thesis\%20Sharon\%20Gogar.pdf

Halabisky, D. (2017). Policy brief on women's entrepreneurship. European Commission $\&$ OECD. Retrieved from https://dspace.ceid.org.tr/xmlui/handle/1/900

Hamilton, E. (2013). The discourse of entrepreneurial masculinities (and femininities). Entrepreneurship \& Regional Development, 25(1-2), 90-99.

Henry, C. (2020). Women enterprise policy and COVID-19: Towards a gender-sensitive response. Retrieved from https://eurogender.eige.europa.eu/system/files/webdiscussions-files/oecd_webinar_women_entrepreneurship_policy_and_covid19 summary report.pdf

Högberg, $\bar{K}$. (2018). Persistent Digital Service Encounters: Challenges of organizational use of social media in a hotel chain. Doctoral dissertation, University West, Retrieved from https://www.divaportal.org/smash/record.jsf?pid=diva2\%3A1206756\&dswid $=9021$

Högberg, K., \& Olsson, A. K. (2019). Framing organizational social media: A longitudinal study of a hotel chain. Information Technology \& Tourism, 21(2), 209-236.

Hunady, J., Orviska, M., \& Pisar, P. (2018). The effect of higher education on entrepreneurial activities and starting up successful businesses. Engineering Economics, 29(2), 226-235.

Ismail, I., Husin, N., Rahim, N. A., Kamal, M. H. M., \& Mat, R. C. (2016). Entrepreneurial success among single mothers: The role of motivation and passion. Procedia Economics and Finance, 37, 121-128.

Javadian, G., \& Singh, R. P. (2012). Examining successful Iranian women entrepreneurs: An exploratory study. Gender in Management: An International Journal, 27(3), 148-164.

Jones, N., Borgman, R., \& Ulusoy, E. (2015). Impact of social media on small businesses. Journal of Small Business and Enterprise Development, 22(4), 611-632.

Kaur, K., \& Kumar, P. (2020). Social media usage in Indian beauty and wellness industry: A qualitative study. The TQM Journal, 33(1), 17-32.

Kaur, S., \& Kaur, A. (2020). Role of social media in sustaining business during corona virus pandemic. International Review of Business and Economics, 4, 411-418.

Kozubíková, L., Vojtovič, S., \& Rahman, A. (2016). The role of entrepreneur's gender, age and firm's age in autonomy: The case study from the Czech Republic. Economics \& Sociology, 9(2), 168-183. 
Kraus, S., Palmer, C., Kailer, N., Kallinger, F. L., \& Spitzer, J. (2018). Digital entrepreneurship: A research agenda on new business models for the twenty-first century. International Journal of Entrepreneurial Behavior \& Research, 25(2), 353-375.

Kritikos, A., Graeber, D., \& Seebauer, J. (2020). Corona-Pandemie wird zur Krise für Selbständige. DIW aktuell, No. 47, Deutsches Institut für Wirtschaftsforschung (DIW), Berlin.

Lemeshow, S., Hosmer, D., Klar, J., \& Lwanga, S. (1997). Adequacy of Sample Size in Health Studies, Chichester: Wiley, 1990.

Mandishaya, H., Inderpal, L.-A., \& Karodia, A. M. (2015). An evaluation of the challenges faced by women owned small to medium enterprises and their impact on organisational performance: a case study of Katter Incubation Centre, Thomas Region , Namibia. Kuwait Chapter of Arabian Journal of Business and Management Review, 5(3), 111-138.

Markowska, M., Ahl, H., \& Naldi, L. (2018). Paths to entrepreneurship: Life stories of Swedish mumpreneurs. 3rd Annual "Entrepreneurship as Practice" Doctoral Consortium and Conference/Workshop, Linnaeus University, Växjö, April 1620.

Melchioly, S. R., \& Sæbø, Ø. (2010). ICTs and Development: Nature of mobile phones usage for SMEs Economic Development-An Exploratory Study in Morogoro, Tanzania. ICT and Development-Research Voices from Africa. International Federation for Information Processing (IFIP), Technical Commission, 9(4), 2015.

Melissa, E., Hamidati, A., \& Saraswati, M. S. (2013). Social media empowerment: How social media helps to boost women entrepreneurship in Indonesian urban areas. The IAFOR Journal of Media, Communication and Film, 1(1), 77-90.

Melissa, E., Hamidati, A., Saraswati, M. S., \& Flor, A. (2015). The Internet and Indonesian women entrepreneurs: Examining the impact of social media on women empowerment. In Impact of information society research in the global south (pp. 203-222). Springer, Singapore.

Mordi, C., Simpson, R., Singh, S., \& Okafor, C. (2010). The role of cultural values in understanding the challenges faced by female entrepreneurs in Nigeria. Gender in Management: An International Journal, 25(1), 5-21.

Mukolwe, E., \& Korir, J. (2016). Social media and entrepreneurship: Tools, benefits, and challenges. A case study of women online entrepreneurs on kilimani mums marketplace on facebook. International Journal of Humanities and Social Science, 6(8), 248-256.

Naidu, N. (2010). Management and entrepreneurship. IK International Pvt Ltd.

OECD. (2021). One year of SME and entrepreneurship policy responses to COVID-19: Lessons learned to "build back better." Retrieved from https://www.oecd.org/coronavirus/policy-responses/one-year-of-sme-andentrepreneurship-policy-responses-to-covid-19-lessons-learned-to-build-backbetter-9a230220/

Olsson, A. K., \& Bernhard, I. (2020). Keeping up the pace of digitalization in small businesses-Women entrepreneurs' knowledge and use of social media. International Journal of Entrepreneurial Behavior \& Research, 27(2), 378-396.

Orser, B. (2020). Women enterprise policy and COVID-19: Towards a gendersensitive response. Retrieved from https://eurogender.eige.europa.eu/system/files/web- 
discussions-files/oecd_webinar_women_entrepreneurship_policy_and_covid19_summary_report.pdf

Orser, B. J., Riding, A. L., \& Manley, K. (2006). Women entrepreneurs and financial capital. Entrepreneurship Theory and Practice, 30(5), 643-665.

Powers, J., \& Magnoni, B. (2013). Pure perseverance: A study of women's small businesses in Colombia: Understanding success factors of women's and men's small businesses in Bucaramanga, Colombia. Colombia, Multilateral Investment Groups.

Rahim, S., Qutoshi, S. B., Abida, S., Muhammad, F., \& Hussain, I. (2020). Access and use of mobile phone in daily life activities by rural women of Gilgit-Baltistan, Pakistan. Mobile Information Systems, June, 1-11.

Sandri, S. H., \& Hardilawati, W. L. (2019). The womenprenenurs: problem dan prospect in digital era. Jurnal Akuntansi dan Ekonomika, 9(1), 93-98.

Shafi, M., Liu, J., \& Ren, W. (2020). Impact of COVID-19 pandemic on micro, small, and medium-sized Enterprises operating in Pakistan. Research in Globalization, 2,100018 .

Sharma, S. (2018). Emerging dimensions of women entrepreneurship: developments \& obstructions. Economic Affairs, 63(2), 295372.

Sultan, S., \& Sultan, W. I. (2020). Women MSMEs in times of crisis: Challenges and opportunities. Journal of Small Business and Enterprise Development, 27(7), 1069-1083.

Ukpere, C. L., Slabbert, A. D., \& Ukpere, W. I. (2014). Rising trend in social media usage by women entrepreneurs across the globe to unlock their potentials for business success. Mediterranean Journal of Social Sciences, 5(10), 551-551.

UN Women. (2020).Leveraging digitalization to cope with covid-19 an Indonesia case study on women-owned micro and small businesses. Retrieved from https://www.unglobalpulse.org/wp-content/uploads/2020/12/IndonesiaDigitalization-Women-MSBs-COVID19-EN.pdf

UNDP, \& LPEM UI. (2021). Impact of Covid-19 pandemic on MSMEs in Indonesia. Retrieved from https://www.id.undp.org/content/indonesia/en/home/library/ImpactofCOVID19M SMEs.html

Vijayakumar, A., \& Jayachitra, S. (2013). Women entrepreneurs in India-Emerging issues and challenges. International Journal of Development Research, 3(4), 1217.

Villaseca, D., Navío-Marco, J., \& Gimeno, R. (2020). Money for female entrepreneurs does not grow on trees: Start-ups' financing implications in times of COVID-19. Journal of Entrepreneurship in Emerging Economies, 13(4), 698-720.

Wei, L. C. (2018). Why women-owned businesses in Indonesia stay small. Retrieved from http://irai.co.id/wp-content/uploads/2018/09/Indonesia-Women-SMEs-ReportFINAL-31-Aug-18.pdf

World Bank Group. (2016). Women entrepreneurs in Indonesia: A pathway to increasing shared prosperity. World Bank.

WTO. (2020). Helping msmes navigate the covid-19 crisis. Retrieved from https://www.wto.org/english/tratop_e/covid19_e/msmes_report_e.pdf 
Yahya, M. M., \& Mutarubukwa, P. A. (2017). Mobile phone usage among women traders in Tanzania: A case of women traders at Kariakoo Area, Dar-Es-Salaam. Business Education Journal, 3(1), 1-10.

Zali, M. R., Faghih, N., Gelard, P., \& Molaei, R. (2018). The impact of age and entrepreneurial age-based self-image on entrepreneurial competencies of male and female: evidence of GEM-Iran 2016 Data. In N. Faghih \& M. R. Zali (Eds.), Entrepreneurship Ecosystem in the Middle East and North Africa (MENA) (pp. 399-418). Springer International Publishing. https://doi.org/10.1007/978-3-31975913-5_13.

Zeb, A., \& Ihsan, A. (2020). Innovation and the entrepreneurial performance in womenowned small and medium-sized enterprises in Pakistan. Science Direct, 79, 102342.

Zuboff, S. (2015). Big other: Surveillance capitalism and the prospects of an information civilization. Journal of Information Technology, 30(1), 75-89. 